\title{
Morphological studies on collared lemmings (Rodentia, Arvicolidae, Dicrostonyx) from Bolshevik Island of the Severnaya Zemlya Archipelago, with notes on evolution and taxonomic position
}

\author{
Natalya I. Abramson, Nikolai G. Smirnov \& Elena P. Tikhonova
}

\begin{abstract}
The variation of molar patterns and lower jaw of collared lemmings from the Bolshevik Island is analyzed. In all teeth except $\mathrm{m} 2$ the morphotype henseli is dominant. Morphotype simplicior is the second most common morphotype in M3. Such type of dentition was typical for the lemmings of the Late Pleistocene and within the recent collared lemmings of Palaearctic was not recorded until now. Morphotype variation in the sample from Bolshevik Island is most similar to that in the sample from the Late Pleistocene Betovo site (36 thousand years BP). By the structure of the lower jaw lemmings from Bolshevik Island differ both from all recent subspecies of the genus, known karyomorphs, mtDNA phylogroups, and lemmings from Betovo.
\end{abstract}

KEY WORDS: collared lemmings, Pleistocene, Severnaya Zemlya, molar patterns variation, morphometric variation, intraspecies taxonomy.

Natalya I. Abramson [lemmus@zin.ru], Zoological Institute, Russian Academy of Science, Universitetskaya nab. 1, St. Petersburg 199034, Russia; Nikolai G. Smirnov [nsmirnov@ecology.uran.ru], Institute of Plant and Animal Ecology, Russian Academy of Science, ul. Vos'mogo Marta 202, Yekaterinburg 620144, Russia; Elena P. Tikhonova [ellobius@zin.ru],Zoological Institute, Russian Academy of Science, Universitetskaya nab. 1, St. Petersburg 199034, Russia.

\section{Морфологическое изучение копытного лемминга (Rodentia, Arvicolidae, Dicrostonyx) острова Большевик архипелага Северная Земля, с заметками по эволюции и таксономическому положению}

\author{
Н.И. Абрамсон, Н.Г. Смирнов, Е.П. Тихонова
}

РЕЗЮМЕ. Изучена изменчивость зубной системы и нижней челюсти копытных леммингов с о-ва Большевик. У леммингов с о-ва Большевик на всех зубах, за исключением второго нижнего, преобладал морфотип henseli, на втором месте был морфотип simplicior. Среди современных копытных леммингов Евразии такого строения зубной системы до сих пор не было отмечено, в то время как для леммингов позднего плейстоцена оно было типичным. Показано, что по набору морф на первом и втором верхних зубах выборка современных леммингов с о-ва Большевик в наибольшей степени сходна с таковым у леммингов из позднеплейстоценового местонахождения Бетово (36 тыс. лет), что позволяет считать их реликтами последней ледниковой эпохи. По строению нижней челюсти лемминги с о-ва Большевик отличаются достоверно как от всех современных подвидов, так и от леммингов из местонахождения Бетово.

КЛЮЧЕВЫЕ СЛОВА: копытные лемминги, плейстоцен, Северная Земля, морфотипическая изменчивость, морфометрическая изменчивость, внутривидовая таксономия.

\section{Introduction}

As compared to other species within the family Arvicolidae collared lemmings (Dicrostonyx Gloger, 1841) demonstrate both the highest temps of molar patterns evolution during the Pleistocene and highest karyotype variability. Due to the latter the taxonomy of the genus remains unstable and the number of recog- nized species within the genus varies from one to eleven. However, geographic variation of pelage color and exterior characters is poorly pronounced and collared lemmings from different parts of the circumpolar range appeared to be so similar that some authors recognized only one Holarctic species, Dicrostonyx torquatus Pallas, 1779 (Ognev, 1948; Corbet, 1978), or two species, D. torquatus in the Palaearctic and D. groenlandicus 
Traill, 1823 in the Nearctic (Hall, 1981). In addition $D$. hudsonius Pallas, 1778 is considered as an independent species that relies on its primitive molar patterns similar with the Late Pleistocene D. simplicior Fejfar, 1966.

The intraspecific variation of various craniometric characters of collared lemmings within the Palaearctic region has been studied repeatedly (Chernyavskii, 1972; Smirnov et al., 1986; Abramson \& Tikhonova, 2002). It is generally accepted to distinguish two lemming species in this region, D. torquatus and $D$. vinogradovi Ognev, 1948. The geographic range of the latter species is restricted to Wrangel Island. Within D. torquatus, two continental subspecies are distinguished,D.t. torquatus Pallas, 1779 and D. t. chionopaes Allen, 1914, whose ranges are separated from each other by the Yenisei River, and one insular subspecies, D. t. ungulatus Baer, 1841 inhabiting the Novaya Zemlya. The taxonomic position of lemmings from the Severnaya Zemlya remains unclear because the lack of material.

In the modern and fossil lemmings of the genus Dicrostonyx, the structure of the molar masticatory surface varies. The analysis of paleontological material showed that different variants predominated in different periods of the genus history (Agadzhanyan, 1976). On the basis of this evidence, several successive species forms have been described. D. simplicior is assumed to be typical form of the Middle Pleistocene, whereas $D$. henseli Hinton, 1910, of the Late Pleistocene. Variants with pronounced additional triangles on molars are considered apomorphic.

Here we examine the morphological variation of molar pattern and dentary structure in the sample of lemmings from Bolshevik Island. These data are used for two purposes. First, comparing the molar patterns with fossil and recent samples we evaluate the level of evolutionary development of their dentition. Second, by the morphometric analysis we evaluate the level of differentiation of this island population as compared to all described subspecies of D. torquatus, known karyomorphs and phylogroups defined on the base of mtDNA variation within the Palaearctic. Combining these data we attempt at least at preliminary level to determine the taxonomic position of these lemmings within a genus.

\section{Material and methods}

Craniodental remains of collared lemmings studied here were extracted from owl pellets collected at the southern extremity of Bolshevik Island in 1983 by V.N. Kalyakin (Geographical Faculty, Moscow State University) who kindly provided us with this material. It contained 17 fragments of skulls with teeth (complete and incomplete tooth rows), 46 dentaries (also with complete and incomplete tooth rows), and isolated teeth: 26 m1's, 12 m2's, $16 \mathrm{M} 1$ 's, $11 \mathrm{M} 2$ 's, and $11 \mathrm{M} 3$ 's.

A tooth was assigned to a morph by measuring the corresponding angle using a technique described by Smirnovetal. (1986), with some later modifications; the criteria were the same for the first and second tooth. A larger angle corresponded to a better developed addi- tional triangle. The scale factor was $5^{\circ}$ and the entire range of measurements was $0-120^{\circ}$. The designation "sim" corresponds to the morph, typical of D. simplicior, which lack any newly formed triangles. The morphs typical of $D$. henseli ("hen") corresponded to angles from $5^{\circ}$ to $50^{\circ}$. Large angles corresponded to the interval of morphs characteristic of D. torquatus ("tor"). In this study, the variation range was divided into five morphs for the first tooth and five morphs for the second one $\left(0^{\circ}\right.$, $5-25^{\circ}, 30-50^{\circ}, 55-75^{\circ}$, and $80^{\circ}$ or higher corresponded to morphs sim, hen1, hen2, tor 1, and tor2, respectively).

The morphs of all the other teeth, namely, the M3 and all lower teeth, were differentiated as described previously by Smirnov et al. (1986). The index of population similarity in polymorphic parameters $(r)$ (Zhivotovskii, 1979) was evaluated to compare the samples qualitatively. In the cases of a complete similarity or dissimilarity $r$ assumes values 1 and 0 , respectively. In a series of tooth samples from fossil remains ofDicrostonyx, whose age was determined by the radiocarbon method, the parameters of similarity were calculated and compared with those of the reference modern sample, and the position of lemmings from Bolshevik Island in this series was determined. The reference sample included skulls from pellets of predatory birds near the Payuta River mouth in the southern Yamal Peninsula near the Polar Urals.

Material under study comes from owl pellets and contains numerous dentaries and few intact skulls. Due to this morphometric analysis was performed only on dentary. The measurements were taken to the nearest $0.1 \mathrm{~mm}$ using dial calipers as described in Abramson \& Tikhonova (2002).

The samples of collared lemmings from Eurasian Arctic from the collection of the Zoological Institute, Russian Academy of Sciences (ZIN) were grouped as described previously by Abramson \& Tikhonova (2002) and were then compared with the sample from Bolshevik Island using the stepwise discriminant function analysis. As from preliminary studies (Abramson \& Smirnov, 2004) it was found that by molar patterns lemmings from Bolshevik Island most similar to the sample from the Betovo site (Late Pleistocene, Russian Plain) we included dentaries of lemmings from this site $(n=21)$ into comparison. All calculations were performed using software Statistica for Windows, version 6.0.

The contribution of individual characters into the differences between the distinguished groups was assessed with ANOVA using one-way design.

\section{Results}

\section{Analysis of molar pattern variation}

In lemmings from Bolshevik Island, thehenseli tooth morphotypes predominated except for $\mathrm{m} 2$ (Tab. 1). All $\mathrm{m} 2$ teeth from our material had the torquatus morphotype. The simplicior morphotype was the second most frequent for M3 and $\mathrm{m} 1$ on the lingual side. This tooth structure is not characteristic of the modern Eurasian 
Table 1. Frequencies of morphotypes torquatus, henseli, simplicior (in \%) in the sample of collared lemmings from the Bolshevik Island (Severnaya Zemlya Archipelago).

\begin{tabular}{|l|c|c|c|c|c|}
\hline tooth & side & $\mathrm{n}$ & simplicior & henseli & torquatus \\
\hline \multirow{2nnyyyy}{*}{ M1 } & & 39 & 0 & 90 & 10 \\
\cline { 3 - 6 } M2 & & 32 & 0 & 69 & 31 \\
\hline \multirow{2}{*}{ M3 } & lingual & 23 & 30 & 70 & 0 \\
\cline { 2 - 6 } & labial & & 39 & 61 & 0 \\
\hline \multirow{2}{*}{ m1 } & lingual & 52 & 23 & 77 & 0 \\
\cline { 2 - 6 } & labial & & 0 & 89 & 11 \\
\hline \multirow{2}{*}{ m2 } & & 40 & - & 0 & 100 \\
\cline { 3 - 6 } m3 & & 37 & - & 100 & 0 \\
\hline
\end{tabular}

Table 2. Frequencies of morphotypes on M1 and M2 in the samples of collared lemmings from the Bolshevik Island and other regions of Eurasian Arctic.

\begin{tabular}{|l|l|c|c|c|c|c|c|c|c|}
\hline \multirow{2}{*}{ Morhotype } & \multirow{2}{*}{ Angle } & \multicolumn{2}{|c|}{ Yamal } & \multicolumn{2}{|c|}{ Bolshevik } & \multicolumn{2}{c|}{ Taimyr } & \multicolumn{2}{c|}{ Chukotka } \\
\cline { 3 - 10 } & & M1 & M2 & M1 & M2 & M1 & M2 & M1 & M2 \\
\cline { 2 - 10 } & & $\mathrm{n}=106$ & $\mathrm{n}=239$ & $\mathrm{n}=39$ & $\mathrm{n}=32$ & $\mathrm{n}=68$ & $\mathrm{n}=68$ & $\mathrm{n}=63$ & $\mathrm{n}=74$ \\
\hline sim & 0 & 1 & 1 & 0 & 0 & 0 & 0 & 0 & 0 \\
\hline hen1 & $5-25$ & 14 & 11 & 59 & 44 & 3 & 1 & 1 & 1 \\
\hline hen2 & $30-50$ & 14 & 11 & 31 & 25 & 15 & 6 & 9 & 7 \\
\hline tor1 & $55-75$ & 45 & 48 & 10 & 25 & 46 & 27 & 28 & 16 \\
\hline tor2 & $80-115$ & 26 & 39 & 0 & 6 & 37 & 66 & 62 & 76 \\
\hline
\end{tabular}
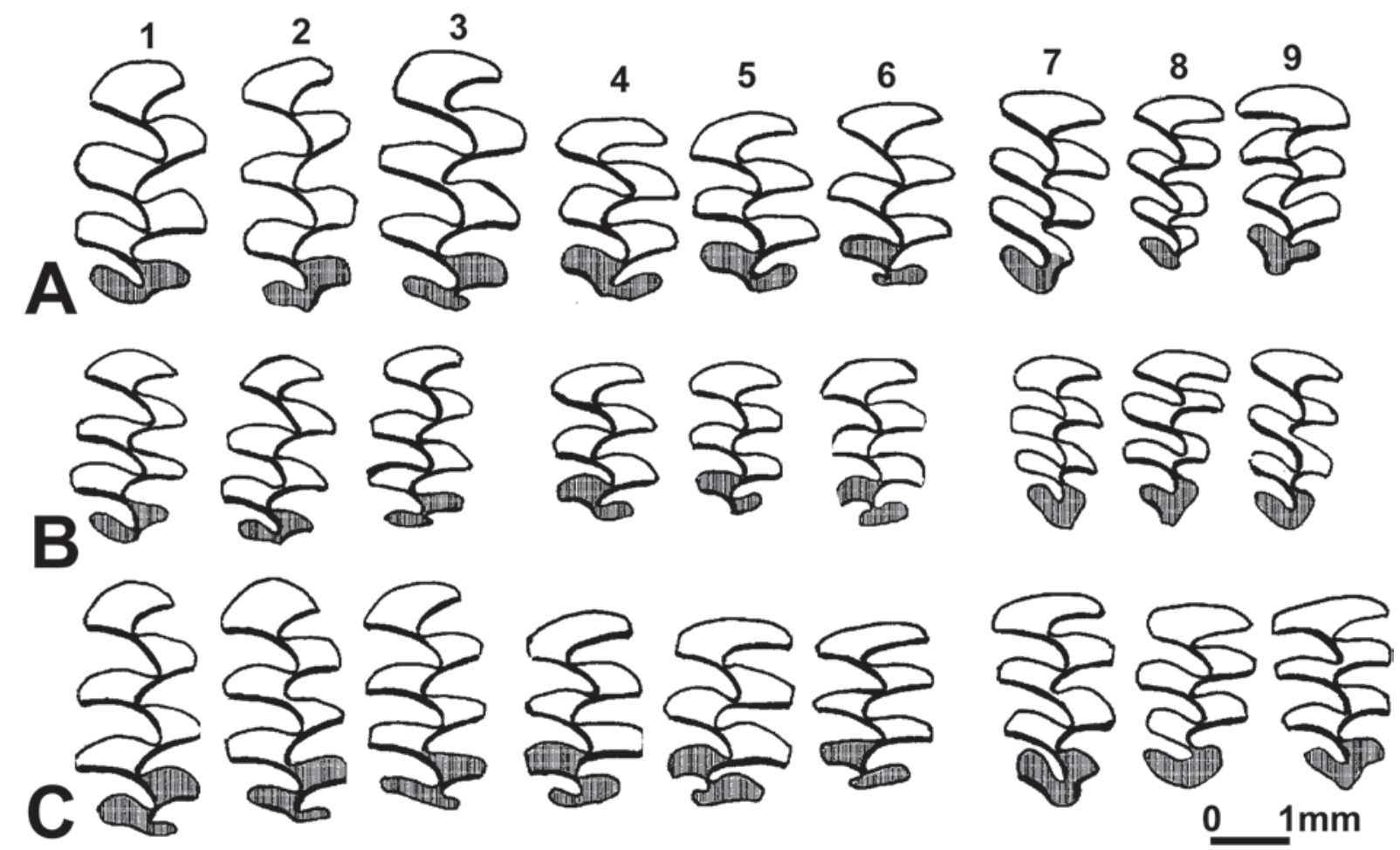

Figure 1. Variation of upper molars in collared lemmings.

A — fossil sample from Betovo; B — recent sample from Bolshevik Island; C — recent sample from North-Western Yamal. 1-3 - M1; 4$6-\mathrm{M} 2 ; 7-9-\mathrm{M} 3$. Varying parts of the teeth are shaded. 


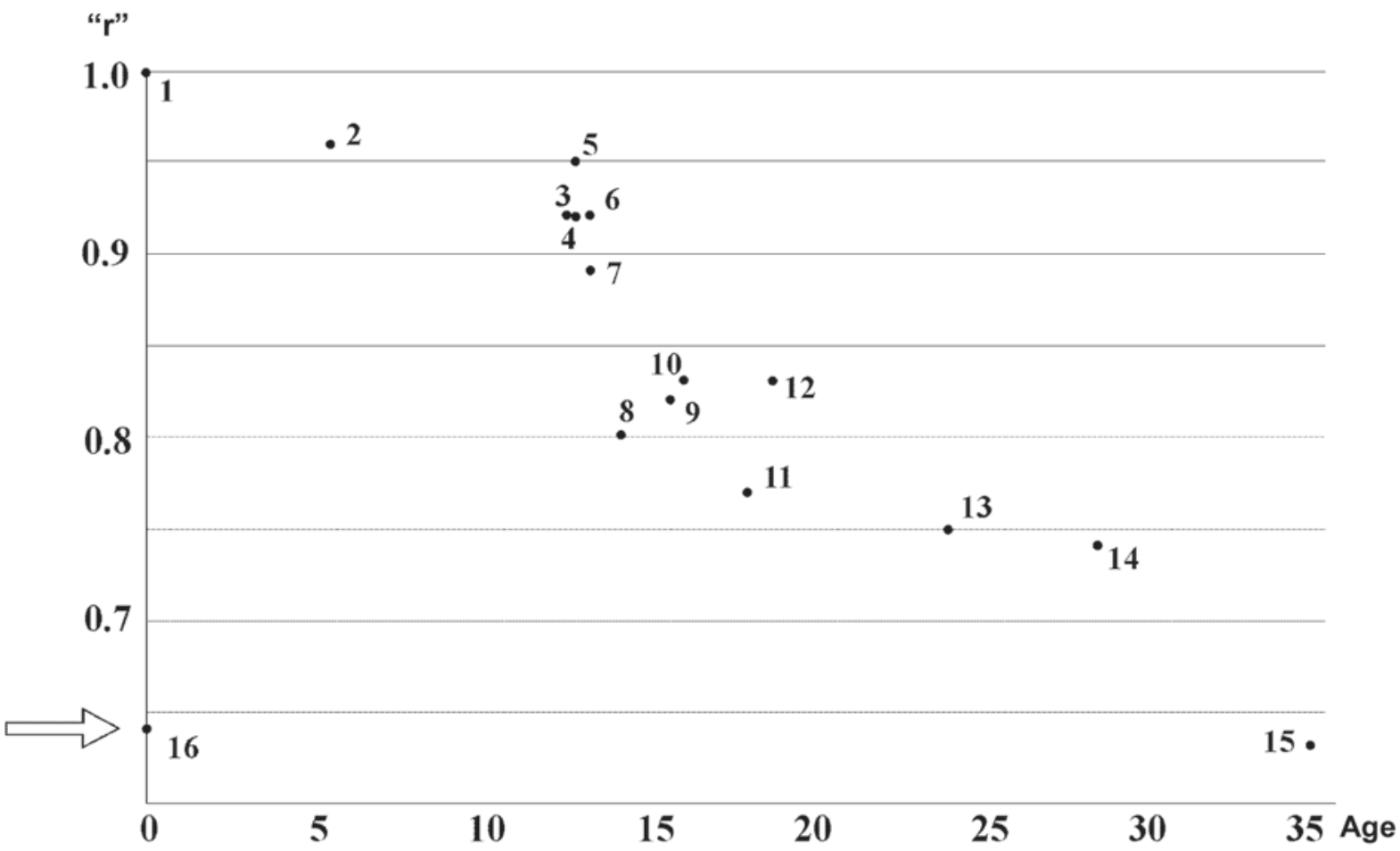

Figure 2. The relationship between the age (thousands years) of Dicrostonyx torquatus (samples 1-7), D. henseli (samples 8-15), and recent collared lemmings from Bolshevik Island (sample 16, $\mathrm{n}=71$ ) and $r$, similarity index between these samples and recent

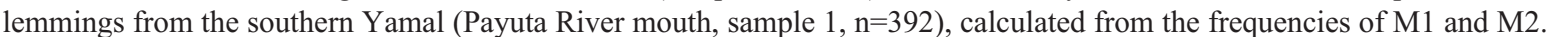

Other samples: 2 - Arakaevo 8 Cave, digging 1, n=39, 5568 300 yBP; 3 - Rasik Grotto, horizon 21, n=340, $12680 \pm 180$ yBP; 4 - Kakva 4, n=41, $12800 \pm 300$ yBP; 5 - Dyrovatyi Kamen' on Chusovaya River, n=225, 12820 \pm 60 yBP; 6 — Rasik, horizon 24, n=418, $13250 \pm 120$ yBP; 7 - Rasik, horizon 27, n=378, 13330 \pm 120 yBP; 8 - Bobylek, layer 2, n=54, $14200 \pm 400$ yBP; 9 - Arakaevo 8, digging 2, horizon $12, \mathrm{n}=65,15739 \pm 590 \mathrm{yBP} ; 10$ - Medvezh'ya Cave, a layer of brown loam, $\mathrm{n}=156,16130 \pm 150 \mathrm{yBP} ; 11$ - Medvezh'ya Cave, a layer of brown loam, $\mathrm{n}=59,17980 \pm 200 \mathrm{yBP} ; 12$ - Cheremykhovo 1, site 4, n=185, 18784 \pm 379 yBP; $13-430 \mathrm{~km}$ from the Ob' River mouth, $\mathrm{n}=81$, $24000 \pm 150$ yBP; 14 - Cheremukhovo 1 , site 1 , horizon $54, \mathrm{n}=53,28520 \pm 850$ yBP; 15 - Betovo, $\mathrm{n}=225,36100 \pm 500$. The arrow indicates the index of similarity to lemmings from Bolshevik Island.

three recognized subspecies of $D$. torquatus. The addition of sample from the Bolshevik Island confirmed the results obtained earlier and besides showed that collared lemmings from Bolshevik Island differ from all known subspecies by the variables considered to the greatest extent (Fig. 3). The graph shows the centroid of each group plotted onto the first two canonical axes. The differences between centroids of the groups are highly significant $(p<0.001)$. The variables that contribute to discrimination of samples most significantly are: length of tooth row and the depth of dentary at the symphysis. It is interesting to note that trends of variation of these variables are similar in both island populations of lemmings (Novaya Zemlya - D. ungulatus and Bolshevik Island). Thus island populations differ from mainland subspecies by relatively long tooth row and relatively small depth of dentary (Fig. 4). As to the lemmings from the sample of Betovo they dramatically differ by the structure of dentary both from all recent subspecies and from lemmings from Bolshevik Island (Figs. 3 and 4). It is noteworthy that the trend of variation of tooth row in the sample from Betovo coincides generally with the islands populations but characterized by dramatically increasing of this variable (Fig. 4A). What concerns the depth of the dentary at the symphysis, the lemmings from Betovo show drastically opposite to all recent lemmings trend of variation, differing by the smallest values of this variable (Fig. 4B).

As compared with four chromosome races distinguished within D. torquatus (Fredga et al., 1999) both island samples (from Bolshevik Island and Novaya Zemlya) differ in dentary structure from all karyotypically studied lemmings. The graph (Fig. 3B) shows the centroid of each sample, representing certain chromosome race, plotted onto the first two canonical axes. The differences between centroids of the island populations and any chromosome races are highly significant, within the chromosome races only the race two significantly differs from others, no difference in morphology is allocated between other races $(\mathrm{p}<0.0001)$.

Similar pattern is found when comparing the dentary structure variation in the sample of Bolshevik Island with that among phylogroups distinguished on the base of mitochondrial cyt b gene gaplotypes (Fedorov et al., 1999). When the total studied material is arranged according to supposed distribution of phylogroups no 


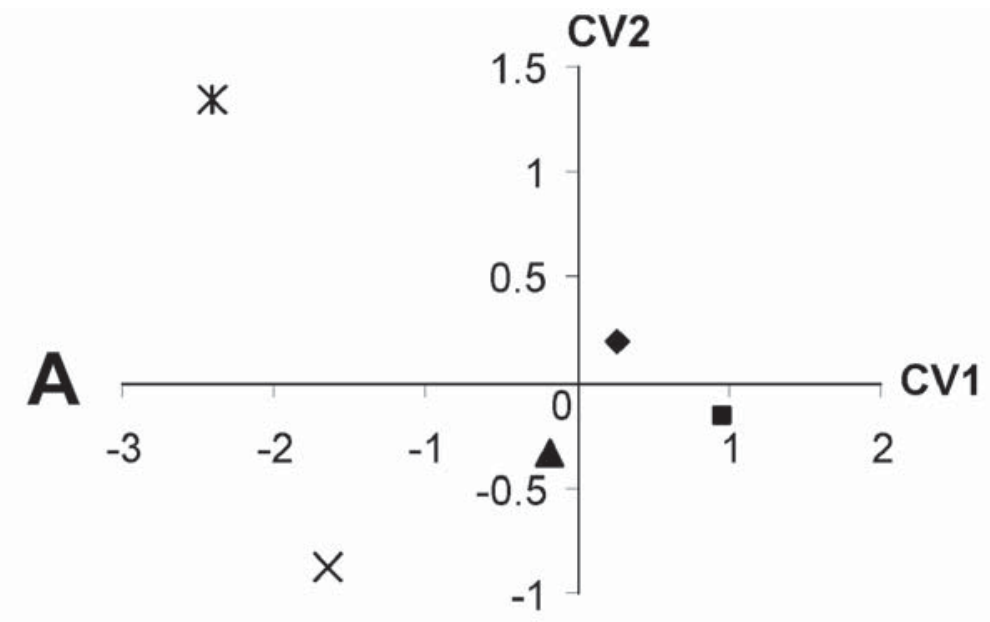

$\checkmark$ torquat.

- chinop.

$\Delta$ ungucul

$\times$ Bolshevik

$*$ Betovo

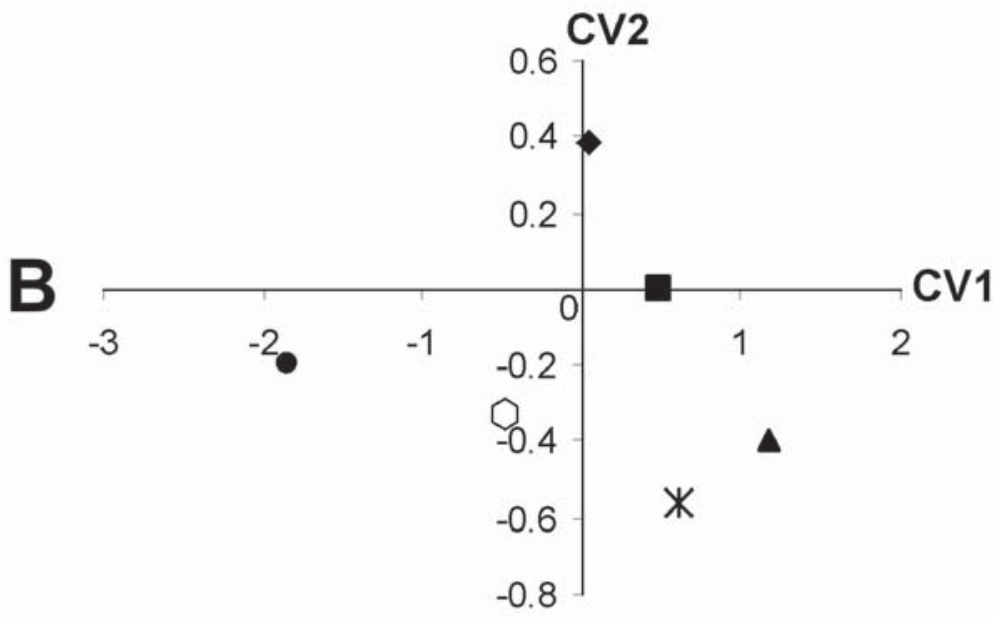

two

one

$\Delta$ four

Oungulatus

$*$ three

- Bolshevik

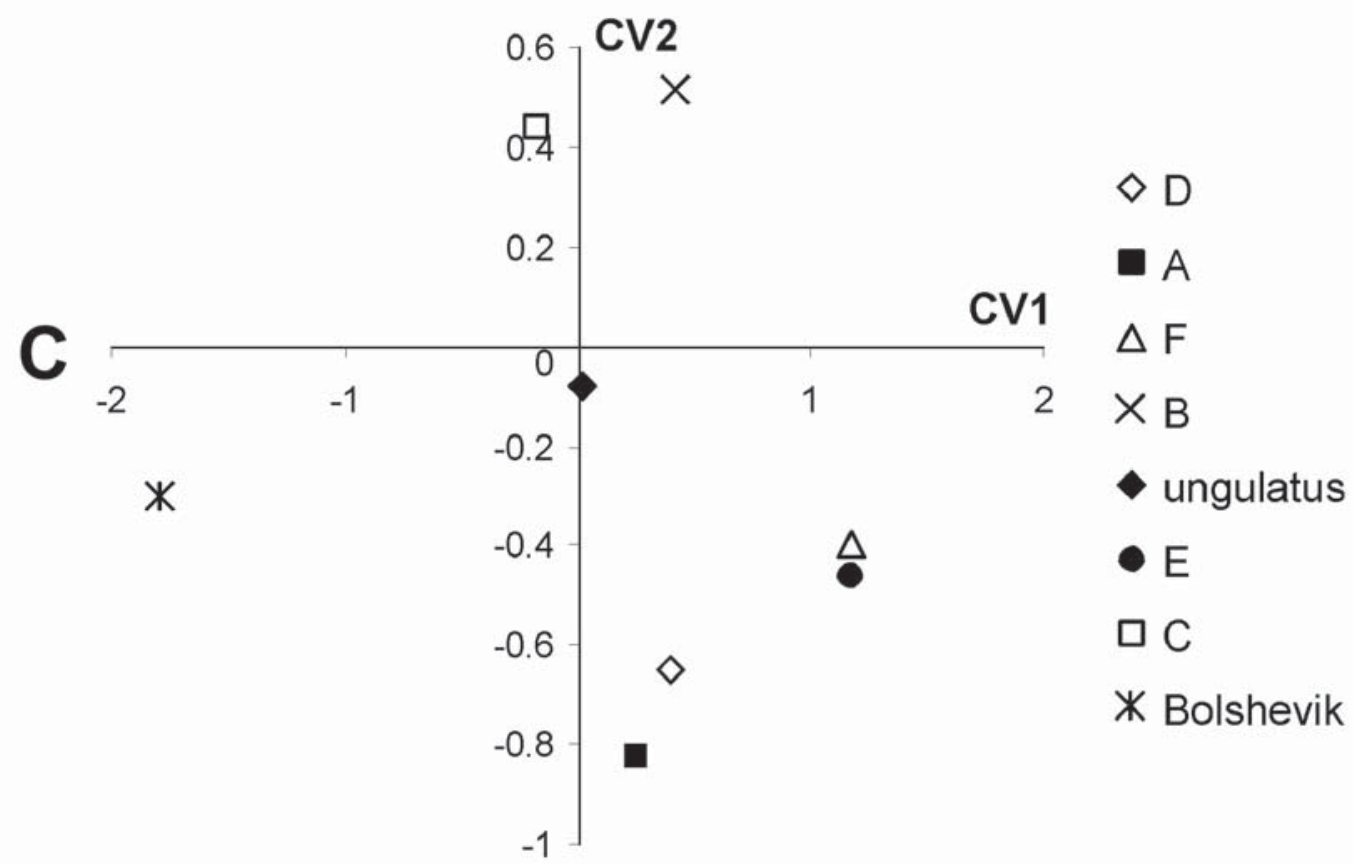

Figure 3. Projections of the centroids of each group plotted onto the first two canonical axes.

A - comparison of sample from Bolshevik Island and Betovo with recent subspecies; B - the same with an account of chromosome races; $\mathrm{C}$ - the same with the account of mitochondrial DNA (cyt.B) clades. 

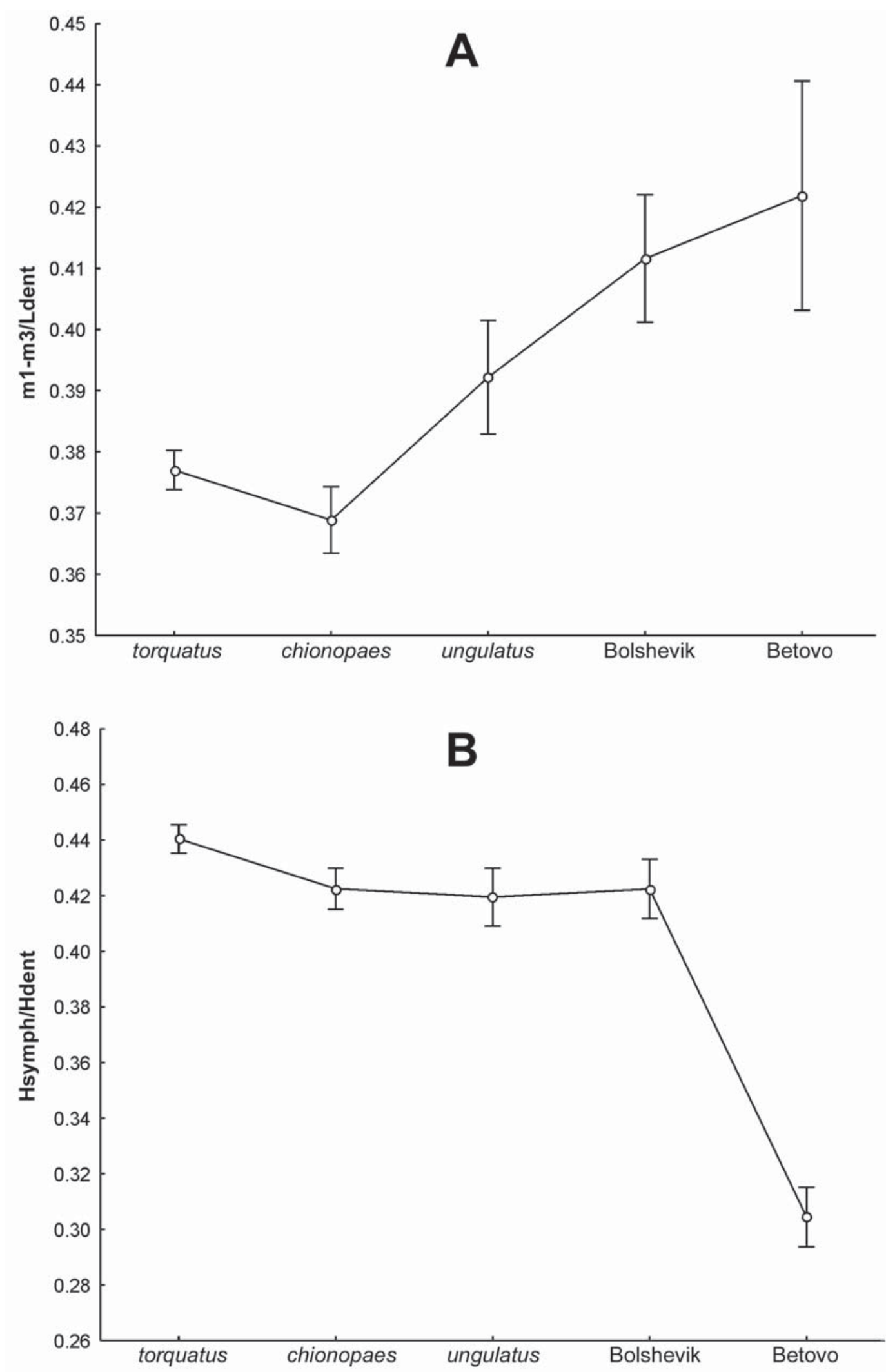

Figure 4. The variation of the relative length of the lower tooth row (A) and relative depth of dentary at the symphysis (B) in the samples of recent subspecies of Dicrostonyx, and samples from Bolshevik Island and Betovo. Vertical bars denote the $95 \%$ significant intervals. 
significant difference is found among the sample of $D . t$. ungulatus and all phylogroups as well as among phylogroups themselves, whereas the sample from Bolshevik differs from all considered samples significantly (Fig. $3 \mathrm{C})$.

\section{Discussion}

The fact that the morphs of the M1 and M2 of modern lemmings from the Bolshevik Island appeared to be most similar to those of fossil lemmings from the Betovo site ( 36000 years BP), suggests that the former lemmings are a relict of the last glacial epoch. Lemmings with the tooth system similar to that of the fossil ancestors were previously found among the modern lemmings of North America. A peculiar species D. hudsonius with a molar form similar to that of the mid-Pleistocene $D$. simplicior inhabits the shores of Hudson Bay. Samples of D. groenlandicus from some Canadian Arctic islands with the structure of the tooth system characteristic of the last glacial period have been recently described (Smirnov \& Fedorov, 2003). Thus, the lemmings from Bolshevik Island may be positioned in the series of relicts between $D$. hudsonius (an analog of Middle Pleistocene forms) and the archaic $D$. groenlandicus (an analog of lemmings of the last glacial period). Why the relict Late Pleistocene form ofDicrostonyx is preserved on Bolshevik Island? The explanation for this phenomenon might lie in the history of the archipelago during the past 550000 years. D.Yu. Bol'shiyanov and V.M. Makeev have hypothesized that glaciers have no significant effect on the relief and deposit formation in the Severnaya Zemlya Archipelago (Bol'shiyanov \& Makeev, 1995). Even the maximum Late Pleistocene (Sar$\tan$ ) and younger Holocene glaciations did not cover the islands completely. Covering glaciations are most likely to have occurred earlier, 90000 to 70000 years ago. The specific natural and climatic development of the Severnaya Zemlya during late Pleistocene explains the fact that the mammoth fauna complex, instead of migrating to the south, migrated slightly northwards compared to the Kargin interglacial period, and the isolation from the continent lasted for at least 12000 years. More and more evidence comes that there was no glaciation in the area of northern and central Taimyr during at least the later part of last glacial cycle (Moller et al., 1999)

The structure of karyotype and cyt b sequence of lemmings from the Severnaya Zemlya Archipelago remain unstudied, but morphological studies reported here showed the rather high level of differentiation from both recognized taxonomic units, chromosome races and mitochondrial phylogroups. The morphological distance between the lemmings from Bolshevik Island and all recognized subspecies of $D$. torquatus is seriously higher than between three subspecies thus defined, what together with peculiar primitive tooth patterns, indicating independent evolutionary history at least since the Late Pleistocene, substantiate distinguishing this form at least as a subspecies. However, only the future studies of
mtDNA and karyotyping will help to make more explicit inference on the history of colonization and taxonomic position of this interesting form.

ACKNOWLEDGMENTS. The authors thank Dr. V.N. Kalyakin for the material supplied on lemmings from the Bolshevik Island and fruitful discussions. This work was supported by the Russian Foundation for the Basic Research (projects 03-04-49179 and 02-04-49181).

\section{References}

Abramson N.I. \& Tikhonova E.P. 2002. Morphometric variation in collared lemming (Rodentia, Arvicolinae, Dicrostonyx) in the Eurasian Arctic in relation to karyotype and mitochondrial DNA diversity // Russian Journal of Theriology. Vol.1. No.2. P.125-132.

Abramson N.I. \& Smirnov N.G. 2004. Lemmings of Bolshevik Island (the Severnaya Zemlya Archipelago) is a Relict of the Last Glacial Epoch // Doklady Akademii Nauk. T.397. No.2. P.570-573 [in Russian].

Agadzhanyan A.K. 1976. [The history of collared lemmings in the Pleistocene] // Kontrimavichus V.L. (ed.). [Beringia in the Cenozoic]. Vladivostok: Dal'nevostochnyi Nauchnyi Tsentr AN SSSR. P. 289-295 [in Russian].

Bol'shiyanov, D.Yu. \& Makeev V.M. 1995 [The Severnaya Zemlya Archipelago: Glaciation and the History of Natural Environment]. Sankt-Peterburg: Gidrometeoizdat. 215 p. [in Russian].

Chernyavskii F.B. 1972. [On the character of geographic variation in some mammal species of the North-Eastern Siberia (the clinal variation and subspecies concept)] // Zhurnal Obshchei Biologii. T.33. No.4. P.437-448 [in Russian with English summary].

Corbet G.B. 1978. The Mammals of the Palaearctic Region: A Taxonomic Review. London, Ithaca: Cornell University Press. 314 p.

Fedorov V.B., Fredga K. \& Jarell G.H. 1999. Mitochondrial DNA variation and the evolutionary history of chromosome races of collared lemmings (Dicrostonyx) in the Eurasian Arctic// Journal of Evolutionary Biology. Vol.12. No1. P.134-145.

Fredga K., Fedorov V.B. \& Jarell G.H. 1999. Genetic diversity in arctic lemmings // Ambio. Vol.28. No.3. P.261269.

Hall E.R. 1981 The Mammals of North America. Second Edition. New York, Chichester, Brisbane, Toronto: John Wiley and sons. $600 \mathrm{p}$.

Moller P., Bolshiyanov D.Yu. \& Bergsten H. 1999. Weichselian geology and palaeoenvironmental history of the central Taymyr Peninsula, Siberia, indicating no glaciation during the last global glacial maximum // Boreas. Vol.28. No.1. P.92-114.

Ognev S.I. 1948. [Mammals of the USSR and Adjacent Countries. T.6]. Moskva-Leningrad: Izdatel'stvo AN SSSR. 559 p. [in Russian].

Smirnov N.G. \& Fedorov V.B. 2003. [Collared lemmings of Holarctic: colonization history as related to the history of Arctic biota] // Ekologiya. No.5. P.370-376 [in Russian]. Smirnov N.G., Bol'shakov, V.N. \& Borodin A.V. 1986 [Pleistocene Rodents of the Northern Regions of Western 
Siberia]. Moskva: Nauka. 143 p. [in Russian]. Zhivotovskii L.A. 1979. Coefficient of similarity of popula- tion on polymorphic characters // Zhurnal Obshchei Biologii. T.40. No.4. P.587-601 [in Russian]. 